\title{
Editorial
}

\section{O design da informação para o aprendizado}

Nesse número temático da InfoDesign buscamos refletir sobre o papel do design na concepção, planejamento, implementação e avaliação de Artefatos de Aprendizagem. Artefatos de aprendizagem são considerados quaisquer materiais, digitais ou não, tais como textos, animação, vídeos, imagens, etc., utilizados de forma isolada ou combinados para fins educacionais. Na criação desses artefatos, o design da informação pode ser aplicado em diferentes graus, com propósitos específicos, e explorando recursos diversos.

Assim, foram considerados artigos que buscam contribuir com uma visão crítica sobre a maneira como as pessoas veem, interpretam e convivem com esses artefatos.

Esse número inicia com a análise imagética de Gomes e Cunha Lima a qual permitiu relacionar escolhas de design com estratégias pedagógicas em seu artigo "Ensinando através de imagens: a linguagem gráfica da apresentação do experimento sobre fotossíntese da planta elódea em livros didáticos brasileiros”. As autoras concluem que a abstenção de alguns livros em utilizar imagens compostas por elementos distintos pode originar-se de uma estratégia pedagógica legitimada pela teoria da aprendizagem construtivista.

Outro importante artefato de aprendizagem é o jogo o qual possui qualidades que facilitam a motivação e engajamento dos alunos. Em "Princípios para o Design de Jogos Digitais com base em Erro Humano" Zaffari e Battaiola apresentam o resultado da pesquisa referente à incorporação, por meio de princípios, do Erro Humano ao design de jogos digitais. A revisão bibliográfica reforça a importância do feedback na experiência do usuário e considera que uma vez que o Erro Humano é inevitável a recuperação desse erro deve ser requisito no sistema. O artigo resume 11 princípios para o design de jogos digitais os quais foram agrupados em 4 categorias: Forçar, Prevenir, Punir e Recuperar.

Os artefatos de aprendizagem também avançam na área de saúde e por isso Freire e Miolo de Oliveira propõem "A criação de estratégia de comunicação para prevenção em saúde através do design centrado no ser humano". Os autores buscam criar estratégias de comunicação voltadas a comportamentos de autocuidado, que objetivam empoderar usuários a mudar seu comportamento. Essas estratégias direcionam para envolvimento do usuário final no processo de construção do artefato.

$\mathrm{Na}$ criação de um artefato de aprendizagem espera-se que o designer adote um posicionamento que visa a superação dos obstáculos encontrados, derivadas de seu repertório e alimentadas pela sua experiência de mundo, transpondo o conhecimento para uma aplicação. Assim, Silva aborda o design enquanto processo 
de resolução de problemas, incluindo heurísticas comuns em tais processos, as suas naturezas de análise e síntese e contribuições da Psicologia Cognitiva em processos de metacognição, criatividade e avaliação em seu artigo "A cognição no processo de design".

Além disso, o compartilhamento de informações sobre o desenvolvimento de artefatos de aprendizagem requer coerência e precisão nos artigos publicados. Por isso, Costa, Mota, Coutinho e Miranda investigam de forma crítica, a estrutura semântica do discurso de textos científicos que foram publicados em congressos e periódico da área do Design da Informação no seu artigo "Estudo piloto sobre o discurso de pesquisas científicas em Design da informação: uma abordagem crítico-semântica da coerência da estrutura textual".

O resultado dessa pesquisa indica que há fragilidade na transmissão de ideias e na coerência entre as estruturas da maioria dos textos observados, apontado a necessidade de atenção na estipulação de objetivos claros e na escolha de metodologias adequadas aos objetivos para, assim, promover conclusões coerentes.

Por fim, Pinheiro, Merino e Gontijo identificam que a definição de inovação em design aparentemente refere-se às alternativas empresariais socialmente aceitas para enfrentar os atuais problemas e os riscos futuros, especialmente através do desenvolvimento de novos produtos voltados para a satisfação das necessidades do mercado. Os autores analisaram 13 artigos sobre inovação os quais são tratados em "Sobre a definição de inovação em design: $\mathrm{O}$ uso da análise de redes para explorar conceitos complexos".

\section{Luciane Fadel}

Editora 